J. Clin. Chem. Clin. Biochem.

Vol. 17, 1979, pp. 77-83

\title{
A Critical Appraisal of a Further Three New Commercial Digoxin Radioimmunoassay Kits with Reference to Cross-Reacting Substances
}

\author{
By W. G. Wood and Christine Wachter
}

Laboratorien für Klinische Chemie und Endokrinologie, Medizinische Klinik Innenstadt der Universität München

(Received July 20/September 11, 1978)

Summary: A further 3 digoxin radioimmunoassay (RIA) kits have been evaluated for performance and cross-reaction with digitoxin, spironolactone, canrenone and furosemide (Lasix-Hoechst). Effects of serum protein concentrations have also been tested. The kits tested were from the following manufacturers:

A) Diagnostic Products Corporation Digoxin RIA Kit.

B) Byk-Mallinckrodt SPAC Digoxin Kit.

C) Boehringer-Mannheim Digoxin RIA Kit.

All kits used a ${ }^{125}$ I-labelled tracer. Kit A used a conventional liquid phase system using double-antibody separation for bound and free drug, Kits B and C used a solid-phase antibody coated tube method.

All kits showed a lower cross-reaction to digitoxin than quoted by the manufacturer.

Cross-reaction to spironolactone (Aldactone - Boehringer-Mannheim) was less than $1.50 \mathrm{nmol} / \mathrm{l}$ at a serum concentration of $125 \mathrm{mg} / \mathrm{A}$ Aldactone in all $3 \mathrm{kits}$. The cross-reaction to canrenone was somewhat higher, $5.2 \mathrm{nmol} / \mathrm{l}$ "digoxin" being measured in one kit at a serum canrenone concentration of $125 \mathrm{mg} / \mathrm{l}$. There was no cross-reaction with furosemide in any kit, even at a serum concentration of $5 \mathrm{~g} / \mathrm{l}$.

The coated-tube assays were affected by serum albumin and globulin concentration changes, one kit showing a difference of over $50 \%$ binding in the range $1-20 \%$ albumin. The double-antibody kit did not show dependence on the concentration of these proteins.

All kits measured digoxin with good reproducibility in the range $0.40-10.0 \mathrm{nmol} / \mathrm{l}$.

Eine kritische Überprüfung von weiteren drei Digoxin-Radioimmunoassay-Kits mit besonderer Rücksicht auf kreuzreagierende Substanzen

Zusammenfassung: Weitere 3 Digoxin Radioimmunoassay (RIA) Kits wurden auf ihre Zuverlässigkeit und ihre Kreuzreaktivität mit Digitoxin, Spironolacton, Canrenon und Furosemid getestet. Ebenso wurden die Effekte von Serumprotẹinen evaluiert.

Folgende Kits wurden getestet:

A) Diagnostic Products Corporation Digoxin RIA Kit

B) Byk-Mallinckrodt SPAC Digoxin Kit

C) Boehringer-Manṇheim Digoxin RIA Kit.

Alle Kits enthielten einèn ${ }^{125}$ I-Tracer.

Kit $\mathbf{A}$ benutzt eine konventionelle Doppelantikörpermethode, während Kit B und Kit C Antikörper-beschichtete Röhrchen verwenden. Alle 3 Kits zeigten eine geringere Kreuzreaktivität mit Digitoxin als vom Hersteller angegeben wurde.

Die Kreuzreaktivität deș Spironolactons (Aldactone - Boehringer-Mannheim) war in allen 3 Kits niedrig $(<1,50$ nmol/1 ,Digoxin" bei einer Aldactonekonzentration im Serum von $125 \mathrm{mg} / \mathrm{l})$. Dagegen war die Kreuzreaktivität mit Cãnrenon höher (bis 5,2 nmol/1 „Digoxin“ bei einer Cạnrenonkonzentration im Serum von $125 \mathrm{mg} / \mathrm{l}$ ).

Furosemid (Lasix-Hoechst) zeigte keine Kreuzreaktion bei einer Konzentration von $5 \mathrm{~g} / \mathrm{l}$. 
Die Coated-Tube Kits zeigten eine erhebliche Störung bei einer Änderung der Konzentrationen von Serumalbumin und $\beta$ - und $\gamma$-Globulinen. Der maximale Unterschied in der Bindung war $>50 \%$ in einem Kit. Der Doppelantikörper-Kit zeigte keine solche Abhängigkeit.

Alle Kits zeigten eine gute Reproduzierbarkeit im Meßbereich 0,40-10,0 nmol/1.

\section{Introduction}

Following a recent publication (1) in which 6 digoxin kits were evaluated, one kit (Boehringer-Mannheim) has been retested with a different antibody, and a further 2 new kits have been included in this follow-up study.

Cross-reaction studies have been made with the most commonly occurring substances and metabolites that might be expected to interfere in the assay of serum digoxin. These were: spironolactone, canrenone, furosemide, digitoxin, serum albumin, $\beta$ - and $\gamma$-globulins. These substances were tested in concentrations below, within and above the normal/therapeutic range. As a measure of the cross-reactivity, the "digoxin"-level was recorded at each concentration of the test-substance; this is a much better way of expressing the cross-reaction than the often used and somewhat misleading concept of displacement at $50 \%$ binding.

\section{Materials and Methods}

The three kits tested were from the following manufacturers:
A) Diagnostic Products Corporation Digoxin Kit (Biosigma GmbH, D-8000 München 21)
B) Byk-Mallinckrodt SPAC Digoxin Kit (Byk-Mallinckrodt GmbH, D-6057 Dietzenbach)
C) Boehringer-Mannheim Digoxin Kit (Boehringer-Mannheim GmbH, D-8132 Tutzing).
In all kits the antigen was labelled with ${ }^{125} \mathrm{I}$.

The Diagnostic Products Corporation (DPC) kit used a conventional double antibody separation, whereas the Byk-Mallinckrod (SPAC) and Boehringer-Mannheim (B-M) kits both employed antibody-coated tubes.

Tables 1 and 2 show the composition of the kits and the incubation schemes.

Digoxin, digitoxin, spironolactone and canrenone were from Boehringer-Mannheim, D-6800 Mannheim.

Human serum albumin was bought from Sigma GmbH, D-8012 Neubiberg, and human $\beta$ - and $\gamma$-globulins from Miles $\mathrm{GmbH}$, D-6000 Frankfurt a. M.

Digoxin-free plasma for all studies was obtained from outdated blood-bank plasma. .

All test súbstances, except the serum proteins, were made up in digoxin-free plasma.

Furosemide (Lasix-Hoechst, D-6000 Frankfurt a. M.) was used from the commercially available solution for intravenous application $(10 \mathrm{~g} / \mathrm{l})$.

Ringer solution (Fresenius) was made up according to DAB 7 and contained $147 \mathrm{mmol} / 1 \mathrm{Na}^{+}, 4.0 \mathrm{mmol} / 1 \mathrm{~K}^{+}, 2.25 \mathrm{mmol} / 1$ $\mathrm{Ca}^{2+}$, and $155 \mathrm{mmol} / \mathrm{l} \mathrm{Cl}^{-}$.
Tab. 1. Characteristics of the 3 kits.

\begin{tabular}{|c|c|c|c|}
\hline & DPC-kit & SPAC-kit & B-M-kit \\
\hline $\begin{array}{l}\text { Pack size } \\
\text { (no. of tests) }\end{array}$ & $100 / 500$ & $50 / 100$ & $60-88$ \\
\hline $\begin{array}{l}\text { Radioactivity } \\
\text { KBq }\end{array}$ & $223 / 1115$ & $74 / 148$ & 223 \\
\hline $\begin{array}{l}\text { Range of } \\
\text { standard curve } \\
\text { nmol/1 }\end{array}$ & $0-10.24$ & $0-6.40$ & $0-6.40$ \\
\hline $\begin{array}{l}\text { No. of } \\
\text { standards }\end{array}$ & 6 & 6 & 5 \\
\hline How packed & $\begin{array}{l}\text { lyophilised } \\
\text { human serum }\end{array}$ & $\begin{array}{l}\text { liquid in } \\
\text { human serum }\end{array}$ & $\begin{array}{l}\text { lyophilised } \\
\text { human serum }\end{array}$ \\
\hline $\begin{array}{l}\text { Control serum } \\
\text { included }\end{array}$ & no & yes & yes \\
\hline $\begin{array}{l}\text { Amount of } \\
\text { standard/ } \\
\text { control sera }\end{array}$ & $\begin{array}{l}2.0 \mathrm{ml} \text { zero } \\
\text { standard } \\
1.0 \mathrm{ml} \text { others }\end{array}$ & $\begin{array}{l}1.5 \mathrm{ml} \text { standard } \\
1.0 \mathrm{ml} \text { control } \\
\text { serum }\end{array}$ & $\begin{array}{l}0.5 \mathrm{ml} \text { stand- } \\
\text { ard and } \\
\text { control serum }\end{array}$ \\
\hline
\end{tabular}

Tab. 2. Incubation and counting schemes.

\begin{tabular}{|c|c|c|c|}
\hline & DPC & SPAC* & B-M* \\
\hline Serum $\mu l$ & 50 & 100 & 100 \\
\hline Buffer + tracer $\mu 1$ & 100 & 1000 & 500 \\
\hline 1st antibody $\mu \mathrm{l}$ & 100 & $\phi$ & $\phi$ \\
\hline 2nd antibody $\mu l$ & 100 & $\phi$ & $\phi$. \\
\hline Incubation & $\begin{array}{l}15 \mathrm{~min}, 37^{\circ} \mathrm{C} \\
+5 \mathrm{~min}, \text { room } \\
\text { temperature }\end{array}$ & $\begin{array}{l}60 \mathrm{~min}, 37^{\circ} \mathrm{C} \\
\text { or } 180 \mathrm{~min} \text {, } \\
\text { room } \\
\text { temperature }\end{array}$ & $\begin{array}{l}60 \mathrm{~min} \text {, } \\
\text { room } \\
\text { tempera- } \\
\text { ture }\end{array}$ \\
\hline $\begin{array}{l}\text { Separation of } \\
\text { bound and } \\
\text { free antigen }\end{array}$ & $\begin{array}{l}2000 \mu \mathrm{l} \\
60 \mathrm{~g} / \mathrm{l} \text { poly- } \\
\text { ethylene } \\
\text { glycol } \\
10 \mathrm{~min} 2000 \mathrm{~g} \\
\text { aspirate super- } \\
\text { natant }\end{array}$ & $\begin{array}{l}\text { aspirate tube } \\
\text { contents }\end{array}$ & $\begin{array}{l}\text { aspirate } \\
\text { tube } \\
\text { contents }\end{array}$ \\
\hline Counting & $\begin{array}{l}\text { tube }+ \\
\text { precipitate }\end{array}$ & tube & tube \\
\hline $\begin{array}{l}\mathrm{Bq} / \text { tube - } \\
\text { zero standard } \\
\text { (new kit) }\end{array}$ & 350 & 200 & 300 \\
\hline Counting time's & 30 & 60 & 30 \\
\hline $\begin{array}{l}\text { Time for } 50 \text {-tube } \\
\text { assay min }\end{array}$ & 75 & $125 / 265$ & 100 \\
\hline
\end{tabular}




\section{Results}

\section{Assay characteristics}

Table 3 shows the binding characteristics and the sensitivity expressed both as the point on the standard curve lying 3 standard deviations (s. d.) from the zero standard (see fig. 1 - lower limit of detection), and

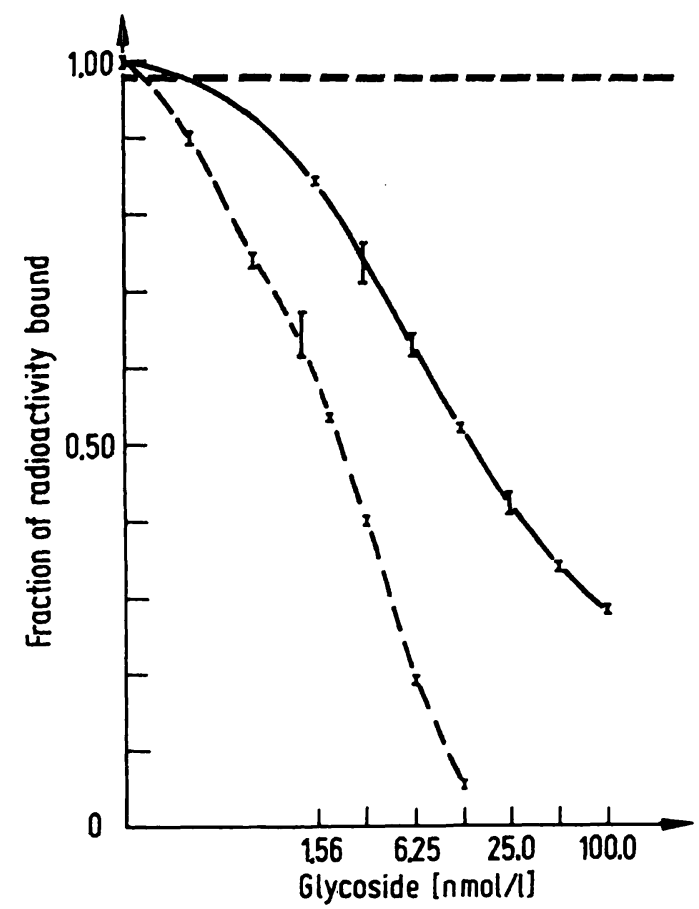

Fig. 1. Standard curve for digoxin (-- ) and digitoxin (-) using the SPAC digoxin kit. The curve was constructed using a spline approximation and the lower detection limits. The 50\% intercept values are: digoxin $2.21 \mathrm{mmol} / \mathrm{l}$; digitoxin $14.4 \mathrm{nmol} / \mathrm{l}$. The vertical bars on the standard curves show the +1 to -1 s.d. range of the binding of the standards. The horizontal bar shows the lower limit of detection. as the $50 \%$ intercept. The DPC kit showed the best reproducibility and binding characteristics in the region of interest, i. e. at both ends of the therapeutic range.

The inter- and intra-assay coefficients of variation (CV) are shown in table 4. Again, the DPC kit gave the best results.

\section{Cross-reactivity studies}

Table 5 shows the reaction of the kits with digoxin and digitoxin in glycoside-free plasma. Table 6 shows the cross-reaction of spironolactone and canrenone in the kits. The cross-reaction is measured as "digoxin" measured at each point tested. This is the better way of showing the interference of spironolactone and canrenone, which can be present in serum at concentrations in excess of 1000 times those of digoxin, and where a percent cross-reactivity can appear deceptively low.

The cross-reaction of digitoxin was lowest in the DPC kit and highest in the SPAC kit. The latter kit can be used to measure digitoxin in serum (see below). All kits measured digoxin within acceptable ranges when the kit standard curve was used as reference, although in the early SPAC kits, there was a considerable negative bias before the kit standards were changed for standards containing correct digoxin concentrations.

The cross-reactivity of spironolactone and canrenone were lowest in the B-M kit. In all kits, however, canrenone reacted with the antibody more than spironolactone.

The cross-reaction with furosemide was not detected in any of the 3 kits tested, even at a concentrations of $5 \mathrm{~g} / \mathrm{l}$.

Tab. 3. Standard curve reproducibility and sensitivity - mean and standard deviation.

\begin{tabular}{|c|c|c|c|}
\hline$\cdot$ & $\begin{array}{l}\text { DPC, } \\
\text { Room temperature }\end{array}$ & $\begin{array}{l}\text { SPAC, } \\
37^{\circ} \mathrm{C}\end{array}$ & $\begin{array}{l}\text { B-M, } \\
\text { Room temperature }\end{array}$ \\
\hline $\begin{array}{l}\text { Sensitivity }{ }^{+} \text {nmol/1 } \\
50 \% \text { intercept }\end{array}$ & $\begin{array}{l}0.19 \pm 0.07 \\
2.05 \pm 0.17\end{array}$ & $\begin{array}{l}0.21 \pm 0.06 \\
2.33 \pm 0.37\end{array}$ & $\begin{array}{l}0.34 \pm 0.04 \\
3.57 \pm 0.56\end{array}$ \\
\hline \multicolumn{4}{|l|}{$\%$ binding of zero standard } \\
\hline $\begin{array}{l}0.51 \text { nmol/l standard } \\
0.64 \\
0.99 \\
1.28 \\
2.24 \\
2.56 \\
3.80 \\
5.12 \\
6.40 \\
10.24 \\
\text { No. of assays used for } \\
\text { calculation of mean and S. D. }\end{array}$ & $\begin{array}{l}\overline{77.9} \pm 2.05 \\
\overline{6} 2.5 \pm 2.30 \\
\overline{44.2} \pm 2.05 \\
\overline{27.9} \pm 1.46 \\
\overline{16.6} \pm 1.23 \\
30\end{array}$ & $\begin{array}{l}83.0 \pm 3.08 \\
\overline{-} \\
65.2 \pm 4.76 \\
\overline{-} \\
47.0 \pm 4.27 \\
34.2 \pm 4.21 \\
\overline{2} 4.0 \pm 4.39 \\
\overline{10}\end{array}$ & $\begin{array}{l}- \\
\overline{81} .9 \pm 2.73 \\
\overline{60} .9 \pm 1.43 \\
\overline{46.9} \pm 4.76 \\
\overline{33.8} \pm 5.27 \\
\overline{10}\end{array}$ \\
\hline
\end{tabular}

+ Sensitivity = Value on standard curve $\times 3$ S. D. from zero. 
Tab. 4. Inter- and intra-assay precision with different control sera.

\begin{tabular}{|c|c|c|c|c|c|c|c|c|c|}
\hline & \multirow[t]{2}{*}{ Intra-assay precision } & \multicolumn{4}{|c|}{$\begin{array}{l}\text { Intra-assay precision } \\
\mathrm{nmol} / \mathrm{l}\end{array}$} & \multicolumn{4}{|c|}{$\begin{array}{l}\text { Inter-assay precision } \\
\text { nmol/1 }\end{array}$} \\
\hline & & $\overline{\mathbf{x}}$ & $s$ & $\mathrm{CV} \%$ & $\mathbf{N}$ & $\bar{x}$ & s & $\mathrm{CV} \%$ & $\mathbf{N}$ \\
\hline 1. DPC & $\begin{array}{l}\text { Quality control serum } \\
\text { RIACON } 1 \\
\text { RIACON } 2 \\
\text { Laboratory Pool D } 1 \\
\text { Laboratory Pool D } 2\end{array}$ & $\begin{array}{l}1.63 \\
4.07 \\
1.15 \\
2.88\end{array}$ & $\begin{array}{l}0.10 \\
0.22 \\
0.07 \\
0.15\end{array}$ & $\begin{array}{l}6.7 \\
5.3 \\
6.2 \\
5.2\end{array}$ & $\begin{array}{l}24 \\
24 \\
20 \\
20\end{array}$ & $\begin{array}{l}1.45 \\
4.00 \\
1.20 \\
3.00\end{array}$ & $\begin{array}{l}0.16 \\
0.37 \\
0.11 \\
0.22\end{array}$ & $\begin{array}{r}11.0 \\
9.2 \\
9.0 \\
7.4\end{array}$ & $\begin{array}{l}53 \\
53 \\
24 \\
24\end{array}$ \\
\hline 2. SPAC & $\begin{array}{l}\text { RIACON } 1 \\
\text { RIACON } 2 \\
\text { NMS I }\end{array}$ & $\begin{array}{l}1.06 \\
2.95 \\
1.07\end{array}$ & $\begin{array}{l}0.11 \\
0.18 \\
0.08\end{array}$ & $\begin{array}{r}12.2 \\
6.1 \\
7.5\end{array}$ & $\begin{array}{l}20 \\
20 \\
20\end{array}$ & $\begin{array}{l}1.00 \\
2.88 \\
-\end{array}$ & $\begin{array}{l}0.15 \\
0.23 \\
-\end{array}$ & $\begin{array}{r}15.0 \\
8.1 \\
-\end{array}$ & $\begin{array}{l}20 \\
20 \\
-\end{array}$ \\
\hline 3. $\mathrm{B}-\mathrm{M}$ & $\begin{array}{l}\text { NMS I } \\
\text { NMS IIa }\end{array}$ & $\begin{array}{l}0.91 \\
2.89\end{array}$ & $\begin{array}{l}0.05 \\
0.23\end{array}$ & $\begin{array}{l}5.6 \\
8.0\end{array}$ & $\begin{array}{l}19 \\
19\end{array}$ & $\begin{array}{l}0.89 \\
2.63\end{array}$ & $\begin{array}{l}0.15 \\
0.32\end{array}$ & $\begin{array}{l}14.8 \\
12.2\end{array}$ & $\begin{array}{l}10 \\
10\end{array}$ \\
\hline
\end{tabular}

Tab. 5. Cross-reactivity of Digitoxin and Digoxin - read from kit standard curve.

\begin{tabular}{|c|c|c|c|c|c|c|}
\hline \multirow[b]{2}{*}{$\begin{array}{l}\text { Digitoxin } \\
\mathrm{nmol} / 1\end{array}$} & \multicolumn{4}{|c|}{$\begin{array}{l}\text { Measured "Digoxin" } \\
\begin{array}{ll}\text { (a) } n m o l / 1 & \text { (b) expressed as \% digitoxin/digoxin in the test sera }\end{array}\end{array}$} & \multirow[b]{2}{*}{$\begin{array}{l}\text { B-M } \\
\text { a }\end{array}$} & \multirow[b]{2}{*}{ b } \\
\hline & $\begin{array}{l}\text { DPC } \\
\text { a }\end{array}$ & $b$ & $\begin{array}{l}\text { SPAC } \\
\text { a }\end{array}$ & b & & \\
\hline $\begin{array}{l}0 \\
1.56 \\
3.12 \\
6.25 \\
12.5 \\
25.0 \\
50.0 \\
100\end{array}$ & $\begin{array}{r}<0.1 \\
<0.1 \\
<0.1 \\
0.12 \\
0.16 \\
0.17 \\
0.47 \\
0.73\end{array}$ & $\begin{array}{l}- \\
- \\
- \\
1.92 \\
1.28 \\
0.68 \\
0.44 \\
0.73\end{array}$ & $\begin{array}{c}<0.1 \\
0.36 \\
0.53 \\
1.38 \\
2.00 \\
2.81 \\
4.05 \\
5.88\end{array}$ & $\begin{array}{c}- \\
23.0 \\
17.0 \\
22.1 \\
16.0 \\
11.2 \\
8.1 \\
5.88\end{array}$ & $\begin{array}{c}<0.1 \\
0.19 \\
0.34 \\
0.52 \\
0.73 \\
0.96 \\
1.61 \\
3.49\end{array}$ & $\begin{array}{r}- \\
12.2 \\
10.9 \\
8.32 \\
5.84 \\
3.84 \\
3.22 \\
3.49\end{array}$ \\
\hline \multicolumn{7}{|l|}{$\begin{array}{l}\text { Digoxin } \\
\text { nmol/1 }\end{array}$} \\
\hline $\begin{array}{l}0 \\
0.31 \\
0.62 \\
1.25 \\
2.5 \\
5.0 \\
10.0\end{array}$ & $\begin{array}{r}<0.1 \\
0.24 \\
0.56 \\
0.96 \\
2.45 \\
4.48 \\
8.85\end{array}$ & $\begin{array}{l}- \\
77.5 \\
90.3 \\
76.8 \\
98.0 \\
89.6 \\
88.5\end{array}$ & $\begin{array}{c}<0.1 \\
0.33 \\
0.61 \\
1.44 \\
2.26 \\
4.19 \\
8.90\end{array}$ & $\begin{array}{c}- \\
106 \\
98.4 \\
115 \\
90.4 \\
83.8 \\
89.0\end{array}$ & $\begin{array}{r}<0.1 \\
0.44 \\
0.89 \\
1.41 \\
2.41 \\
5.92 \\
12.11\end{array}$ & $\begin{array}{r}- \\
141 \\
142 \\
113 \\
96 \\
118 \\
121\end{array}$ \\
\hline
\end{tabular}

Effects of different serum-proteins on the maximum binding

Table 7 shows the effects of albumin $(1-20 \%)$ and $\beta$ - and $\gamma$-globulins ( $1-5 \%)$ on the maximum binding. The proteins were dissolved in Ringer solution, so that only the protein under test was present in the tube. The $100 \%$ binding is the binding given by the zero standard in each kit. Both coated tube kits showed large differences in binding at different albumin concentrations; with the globulins, and with low concentrations of albumin, binding was well above $100 \%$. The DPC kit, using conventional double antibody separation was affected little or not at all by the serum protein concentration.

\section{Effects of aldactone therapy} on measured digoxin concentrations

Table 8 shows.the measured digoxin concentration in 12 patients on spironolactone therapy. The glycoside and spironolactone dosages are shown, as well as serum creatinine as the index of renal function. Large discrepancies are to be seen in the recorded digoxin levels in 2 patients (Nos. 130 and 139). In the other 10 patients no trend is observable between results from the different kits.

\section{Standards measured in all kits}

Table 9 shows the standards in the 3 kits as measured in the other 2 kits. For the SPAC kit the results in brackets were those from the earlier kits with the wrong concentrations above $1.28 \mathrm{nmol} / \mathrm{l}$. The $\overline{\mathrm{DPC}}$ kit measures the expected digoxin values in all kits. The coated tube kits showed some discrepancies. All standards showed a normal electrophöresis pattern with a total serum protein of between 52 and $63 \mathrm{~g} / \mathrm{l}$. 
Tab. 6. Cross-reactivity of Spironolactone and Canrenone read off against kit standard curve.

\begin{tabular}{|c|c|c|c|}
\hline \multirow[t]{2}{*}{$\begin{array}{l}\text { Spironolactone } \\
\mathrm{mg} / 1\end{array}$} & \multicolumn{3}{|c|}{$\begin{array}{l}\text { Measured "Digoxin" } \\
\text { nmol/1 }\end{array}$} \\
\hline & DPC & SPAC & B-M \\
\hline $\begin{array}{l}0 \\
0.975 \\
1.95 \\
3.90 \\
7.80 \\
15.6 \\
31.2 \\
62.5 \\
125\end{array}$ & $\begin{aligned} &< 0.1 \\
&< 0.1 \\
&< 0.1 \\
&< 0.1 \\
& 0.14 \\
& 0.19 \\
& 0.35 \\
& 0.69 \\
& 0.94\end{aligned}$ & $\begin{array}{l}<0.1 \\
<0.1 \\
<0.1 \\
0.17 \\
0.33 \\
0.43 \\
0.50 \\
0.59 \\
0.87\end{array}$ & $\begin{aligned}< & 0.1 \\
< & 0.1 \\
< & 0.1 \\
& 0.15 \\
& 0.10 \\
& 0.22 \\
& 0.36 \\
& 0.56 \\
& 0.84\end{aligned}$ \\
\hline \multicolumn{4}{|l|}{$\begin{array}{l}\text { Canrenone } \\
\mathrm{mg} / 1\end{array}$} \\
\hline $\begin{array}{l}0 \\
0.125 \\
0.250 \\
0.500 \\
0.975 \\
1.95 \\
3.90 \\
7.80 \\
15.6 \\
31.2 \\
62.5 \\
125\end{array}$ & $\begin{array}{c}<0.1 \\
<0.1 \\
0.13 \\
0.18 \\
0.20 \\
0.37 \\
0.42 \\
0.43 \\
0.98 \\
1.67 \\
2.89 \\
3.57\end{array}$ & $\begin{aligned} &< 0.1 \\
&< 0.1 \\
&< 0.1 \\
&< 0.1 \\
& 0.35 \\
& 0.41 \\
& 0.58 \\
& 0.78 \\
& 1.23 \\
& \\
& 2.17 \\
& 3.81 \\
& 5.61\end{aligned}$ & $\begin{aligned}< & 0.1 \\
< & 0.1 \\
< & 0.1 \\
< & 0.1 \\
< & 0.1 \\
& 0.28 \\
& 0.28 \\
& 0.41 \\
& 0.57 \\
& 0.94 \\
& 1.76 \\
& 2.54\end{aligned}$ \\
\hline
\end{tabular}

Tab. 7. Effect of albumin and globulin concentration on the maximum binding.

\begin{tabular}{|c|c|c|c|}
\hline \multirow{2}{*}{$\begin{array}{l}\text { Albumin }(\mathrm{g} / \mathrm{l}) \text { in } \\
\text { Ringer solution }\end{array}$} & \multicolumn{3}{|c|}{$\%$ binding $-100 \%=$ kit zero standard } \\
\hline & DPC & SPAC & B-M \\
\hline $\begin{array}{r}10 \\
20 \\
40 \\
60 \\
80 \\
120 \\
160 \\
200\end{array}$ & $\begin{array}{r}100 \\
102 \\
100 \\
101 \\
101 \\
97 \\
98 \\
98\end{array}$ & $\begin{array}{r}130 \\
127 \\
108 \\
102 \\
100 \\
92 \\
88 \\
79\end{array}$ & $\begin{array}{l}133 \\
139 \\
124 \\
129 \\
128 \\
113 \\
108 \\
105\end{array}$ \\
\hline \multicolumn{4}{|l|}{$\begin{array}{l}\beta \text {-Globulin }(\mathrm{g} / \mathrm{l}) \text { in } \\
\text { Ringer solution }\end{array}$} \\
\hline $\begin{array}{l}10 \\
20 \\
30 \\
40 \\
50\end{array}$ & $\begin{array}{l}102 \\
104 \\
104 \\
104 \\
104\end{array}$ & $\begin{array}{l}142 \\
140 \\
139 \\
135 \\
133\end{array}$ & $\begin{array}{l}134 \\
130 \\
126 \\
118 \\
114\end{array}$ \\
\hline \multicolumn{4}{|c|}{$\begin{array}{l}r \text {-Globulin }(g / 1) \text { in } \\
\text { Ringer solution }\end{array}$} \\
\hline $\begin{array}{l}10 \\
20 \\
30 \\
40 \\
40 \\
50\end{array}$ & $\begin{array}{l}103 \\
104 \\
106 \\
106 \\
106\end{array}$ & $\begin{array}{l}145 \\
144 \\
142 \\
138 \\
139\end{array}$ & $\begin{array}{l}136 \\
133 \\
134 \\
132 \\
128\end{array}$ \\
\hline
\end{tabular}

The measurement of digitoxin in serum with the SPAC kit

Figure 1 shows the standard curves for digoxin and digitoxin in the SPAC digoxin kit. Both curves were set up using pure digoxin or digitoxin added to digitalisfree serum. The lowest detectable limit for digitoxin is around $1 \mathrm{nmol} / 1$ with a $50 \%$ intercept of $14.4 \mathrm{nmol} / \mathrm{l}$. The kit allows measurement of digitoxin up to $50 \mathrm{nmol} / \mathrm{l}$ which covers both therapeutic and toxic levels.

\section{Correlation of results}

Table 10 shows the correlation of results in 67 patients undergoing digoxin therapy. The sera were measured in all kits in a single assay, the assays being carried out on the same day. All correlation coefficients are, as to be expected, highly significant but do not approach the ideal regression equation with $\mathrm{a}=0$ and $\mathrm{b}=1$.

\section{Discussion}

The cross-reaction of digoxin antisera with digitoxin can be used to advantage when it is large enough to allow a digitoxin standard curve to be plotted which covers the range of digitoxin found in patients undergoing treatment with this glycoside. The therapeutical levels of digitoxin in serum as found by Smith (2) were $22 \pm 10 \mathrm{nmol} / \mathrm{l}$ for non-toxic cases, and $44 \pm 8 \mathrm{nmol} / \mathrm{l}$ for toxic cases.

The cross-reaction of digoxin antisera with digitoxin is not linear throughout the concentration range as seen in table 5 , and it is often confusing to read in kit instructions that for example, the cross-reaction of the kit antisera to digitoxin is $10 \%$.

The SPAC-kit allows measurement of digitoxin in serum as seen in figure 1 . As a practical example, a patient was admitted to the emergency ward, unconscious and suspected of having digitalis overdose. The preparation was unknown. With the SPAC-kit the patient serum gave a "digoxin" level of $3.42 \mathrm{nmol} / 1$ and a "digitoxin" level of $38 \mathrm{nmol} / 1$. The DPC-kit gave a "digoxin" level of $0.28 \mathrm{nmol} / \mathrm{l}$. Both SPAC values were in the toxic range whereas that from the DPC-kit was under the therapeutic range. The digitalis preparation was later confirmed to be Digimerck, a digitoxin preparation. The SPAC-kit gave useful information in this case and the DPC-kit would have registered no case of intoxication due to its low cross-reactivity to digitoxin!

The coated tube kits gave problems with abnormally serum protein concentrations which could be a hindrance in the case of serum from dialysis patients and others with dysproteinaemia. Effects of serum proteins and renal insufficiency have been described in part for both ${ }^{125} \mathrm{I}$ - and ${ }^{3} \mathrm{H}$-methods (3-7). It has been known for some time that simultaneous spironolactone (Aldactone) treatment and digoxin therapy 
Tab. 8. Measured Digoxin concentrations in 12 patients on Spironolactone therapy;

\begin{tabular}{rlllcccc}
\hline Patient No. & Digoxin dose & Application & \multicolumn{2}{l}{$\begin{array}{l}\text { Spironolactone } \\
\text { mg/d }\end{array}$} & & Creatinine & \multicolumn{2}{c}{ Measured Digoxin levels nmol/1 } \\
mg/d & mg/l & DPC & SPAC & B-M \\
\hline 19 & $0.375 \mathrm{~L}$ * & oral & 100 & 9 & 1.0 & 0.66 & 1.2 \\
21 & $0.125 \mathrm{~L}$ & oral & 200 & 17 & 2.6 & 2.1 & 2.4 \\
24 & $0.250 \mathrm{~L}$ & oral & 200 & -2.7 & 2.8 & 1.7 & 2.3 \\
43 & $0.062 \mathrm{~L}$ & i. v. & 200 & 22 & 2.4 & 3.0 & 2.9 \\
53 & $0.250 \mathrm{~L}$ & i. v. & 400 & - & 1.1 & 1.4 & 1.7 \\
90 & $0.400 \mathrm{~N} * *$ & oral & 200 & 10 & 2.4 & 3.2 & 2.8 \\
106 & $0.250 \mathrm{~L}$ & oral & 200 & 10 & 0.75 & 1.8 & 2.5 \\
107 & $0.250 \mathrm{~L}$ & oral & 200 & 14 & 3.9 & 5.6 & 4.1 \\
124 & $0.375 \mathrm{~L}$ & oral & 200 & 9 & 10.0 & 8.6 & 6.2 \\
130 & $0.125 \mathrm{~L}$ & i. v. & 200 & 11 & 7.5 & 4.6 & 4.9 \\
139 & $0.500 \mathrm{~L}$ & oral & 800 & 28 & 1.0 & 0.74 & 1.2 \\
175 & $0.300 \mathrm{~N}$ & oral & 100 & 5 & & & \\
\hline
\end{tabular}

* $\mathrm{L}=$ Lanicor (Digoxin, Boehringer-Mannheim)

** $\mathrm{N}=$ Novodigal ( $\beta$-Acetyl-Digoxin, Merck)

Tab. 9. Measured Digoxin concentration of standards in other kits.

\begin{tabular}{|c|c|c|c|c|}
\hline $\begin{array}{l}\text { DPC standards } \\
\text { nmol/1 }\end{array}$ & s DPC kit & SPAC kit & B-M & kit \\
\hline $\begin{array}{l}0 \\
0.64 \\
1.28 \\
2.56 \\
5.12 \\
10.24\end{array}$ & $\begin{array}{l}- \\
- \\
- \\
- \\
- \\
-\end{array}$ & $\begin{array}{cc}(<0.1) & <0.1 \\
(<0.1) & 0.25 \\
(0.43) & 0.78 \\
(1.06) & 1.43 \\
(2.51) & 2.90 \\
(5.39) & 7.55\end{array}$ & $\begin{array}{r}0.23 \\
0.87 \\
1.30 \\
2.16 \\
5.75 \\
11.84\end{array}$ & \\
\hline \multicolumn{5}{|l|}{$\begin{array}{l}\text { *SPAC } \\
\text { standards } \\
\text { nmol/l }\end{array}$} \\
\hline $\begin{array}{l}0 \\
0.51 \\
1.28 \\
2.56 \\
3.84 \\
6.40\end{array}$ & $\begin{array}{cc}(<0.1) & <0.1 \\
(0.57) & 0.50 \\
(1.20) & 1.27 \\
(2.52) & 2.55 \\
(4.53) & 3.78 \\
(8.35) & 6.30\end{array}$ & $\begin{array}{l}- \\
- \\
- \\
- \\
-\end{array}$ & $\begin{array}{c}(<0.1)< \\
(0.33) \\
(0.83) \\
(1.88) \\
(3.34) \\
(5.11)\end{array}$ & $\begin{array}{l}0.1 \\
0.29 \\
0.86 \\
2.00 \\
3.49 \\
4.55\end{array}$ \\
\hline \multicolumn{5}{|l|}{$\begin{array}{l}\text { Boehringer- } \\
\text { Mannheim } \\
\text { standards } \\
\text { nmol/l }\end{array}$} \\
\hline $\begin{array}{l}0 \\
0.99 \\
2.24 \\
3.82 \\
6.40\end{array}$ & $\begin{array}{c}<0.1 \\
1.05 \\
2.21 \\
3.58 \\
6.66\end{array}$ & $\begin{array}{cc}(<0.1)< & 0.1 \\
(0.31) & 0.50 \\
(1.04) & 1.45 \\
(1.74) & 2.35 \\
(3.11) & 5.00\end{array}$ & $\begin{array}{l}- \\
- \\
- \\
-\end{array}$ & \\
\hline
\end{tabular}

* During this test the standards were changed. The values of the old standards as measured are shown in parentheses. Values are the means from at least 3 assays in which each standard was run in duplicate.

often give rise to toxic serum digoxin levels, even though no symptoms of an overdose are evident. Spironolactone has a similar structure to digoxin and has a digoxin antagonist effect (8). It also cross-reacts with some digoxin antisera which can cause havoc, since spironolactone may be present in serum at concentrations
Tab. 10. Correlation between the 3 kits, using sera from patients undergoing Digoxin therapy.

\begin{tabular}{lrlll}
\hline & $\mathrm{a}$ & $\mathrm{b}$ & $\mathrm{r}$ & $\mathrm{n}$ \\
\hline DPC v SPAC & -0.01 & 0.87 & 0.928 & 67 \\
DPC v B-M & 0.36 & 0.86 & 0.896 & 67 \\
SPAC v B-M & 0.26 & 0.94 & 0.911 & 67 \\
\hline
\end{tabular}

Linear regression equation $y=a+b x$

The first kit is on the $x$-axis

In all cases $\mathrm{p}<0.001$.

Digoxin levels measured in the three kits in these 67 patients were (mean and range)

DPC Kit $1.82 \mathrm{nmol} / 1(0.30-10.0 \mathrm{nmol} / \mathrm{l})$

SPAC Kit $1.64 \mathrm{nmol} / 1(0.37-8.60 \mathrm{nmol} / 1)$

B-M Kit $1.60 \mathrm{nmol} / 1(0.41-6.20 \mathrm{nmol} / \mathrm{l})$

above 1000 times that of digoxin. Spironolactone is rapidly metabolised in the body to several metabolites with differing biological and immunological properties (9). At least 9 metabolites have been classified (9) of which canrenone and canrenoic acid are the main ones (9-10).

The affinity of canrenone for the digoxin antisera was higher than that shown by spironolactone for the anti- sera tested here, although the concentrations of canrenone in serum are usually much lower than those for spironolactone. Assuming a complete distribution in the blood, the maximum spironolactone levels after a $200 \mathrm{mg} \mathrm{i} / \mathrm{v}$ dose with a blood volume of 5 liters would be $40 \mathrm{mg} / \mathrm{l}$. The maximum canrenone levels in serum are obtained about $2 \mathrm{~h}$ after administration of spironolactone. After à single dose of $200 \mathrm{mg}$ spironolactone, the maximal canrenone concentration observed by Karim and co-workers was $0.40 \mathrm{mg} / 1$ (9). Over longer periods of spironolactone therapy, canrenone accumulates in the serum, its half-life being. $18-22 \mathrm{~h}$. A steadystate is reached after 7-10 days of spironolactone 
therapy, when the minimum canrenone levels measured ( $24 \mathrm{~h}$ after the last spironolactone dose) were: up to $0.9 \mathrm{mg} / 1$ for $200 \mathrm{mg}$, up to $1.7 \mathrm{mg} / 1$ for $300 \mathrm{mg}$ and up to $2.6 \mathrm{mg} / \mathrm{l}$ for $400 \mathrm{mg}$ spironolactone per day (9). In one case of congestive heart failure, serum canrenone levels of $4.3 \mathrm{mg} / \mathrm{l}$ were measured in a patient taking Soldactone (potassium canrenoate). Other metabolites of spironolactone and canrenoic acid are known to have halflives of longer than 50 days (9), and are therefore likely to accumulate in the body during therapy. These metabolites have neither been characterised nor tested for reaction with digoxin antisera. Although only minimally elevated digoxin levels may be expected in serum of patients on spironolactone therapy, unexpectedly high levels are occasionally seen in some kits, as seen in patients 130 and 139 in Table 8 with the DPC-kit. Neither of these patients had ECG patterns which would indicate digitalis poisoning. In rats undergoing digoxin therapy with and without spironolactone (8), it was found that spironolactone increased the excretion of digoxin metabolites from 72 to $98 \%$ of the given digoxin dose; this may indicate, that under Aldactone therapy, there is an increased metabolism of digoxin to less biologically active metabolites which may still show immunoreactivity with certain antisera to digoxin. This, together with the antagonist action of spironolactone (8), may explain why some patients exhibit high immunoreactive digoxin levels without the accompanying ECG changes and without complaining of "yellow-vision" often seen in digitalis intoxication patients.

Bearing these facts in mind, care must be used when interpreting results from patients on either spironolactone or canrenoate therapy.

There was no cross-reaction of the three antibodies to furosemide, which is probably to be expected as this molecule shows no spatial similarities to digoxin.
The coefficients of variation, both intra- and interassay, were greater in the coated tube kits, as already shown previously (1). The stability of the standard curves in serial assays is good, but not good enough for a short-cut suggested by Boehringer-Mannheim in their kit instructions. Here, it is stated that the standard curve tubes used in one assay can be stored and used in subsequent assays over the next 14 days, provided that the quality-control serum, supplied in the kit, and run with each assay, gives results from this standard curve which lie within the prescribed limits. This is a false economy step which contravenes all accepted quality-control concepts.

The instructions contained in each kit gave detailed information on carrying out the test, and in the case of the DPC and SPAC kits, also the clinical relevance of the test. The DPC-kit in its original form had more useful data on recovery experiments and inter- and intra-assay variation.

The SPAC-kit contained one mistake in the French and English versions, that of the cross-reaction of the antibody with $\beta$-acetyl digoxin at $40 \%$, whereas in the German edition it is given, correctly, at $90 \%$.

To conclude, this study has shown that of the 3 kits tested none is ideal for all situations, a finding which repeats those of an earlier investigation (1).

\section{Acknowledgements}

Thanks are expressed to Fa. Byk-Mallinckrodt and Fa. Boehringer-Mannheim for supplying the kits for this study free of charge and also to Professor Dr. P. C. Scriba for critical reading of the manuscript.

\section{References}

1. Wood, W. G. (1977), this J. 15, 679-685.

2. Smith, T. W. (1970), J. Pharmacol. Exp. Ther. 175, 352-360.

3. Lukas, D. S. \& de Martino, A. G. (1969), J. Clin. Invest. 48, 1041-1053.

4. Belpaire, F. M., Bogaert, M. G. \& de Broe, M. E. (1975), Clin. Chim. Acta 62, 255-261.

5. Evered, D..C. (1972), Eur. J. Pharmacol. 18, 236-244.

6. Taubert, K. \& Shapiro, W. (1975), Am. Heart J. 89, 79-86.

7. Kubisik, N. P., Norkus, N. S. \& Sine, H. E. (1974), Clin. Biochem. 7, 307-312.

8. Karim, A., Kook, C., Zitzewitz, D. J., Zagarella, J., Doherty, M. \& Campion, J. (1976), Drug Metab. Dispos. 4, 547-561.

9. Sadée, W., Schröder, R., von Leitner, E. \& Dagcioglu, M. (1974), Eur. J. Clin. Pharmacol. 7, 195-200.

10. Yeh, B. K. \& Sung, P. K. (1972), Eur. J. Pharmacol. 19, $151-155$.

Dr. W. G. Wood, Laboratorien für Klinische Chemic und Endokrinologie, Medizinische Klinik Innenstadt der Universität München, D-8000 München 2 
-

$$
\cdot
$$

